\title{
Gender representation and language politeness in speech acts: A pragmatic study
}

\section{Representasi gender dan kesantunan berbahasa dalam tindak tutur: Kajian pragmatis}

\author{
Widyatmike Gede Mulawarman*, Yusak Hudiyono, Andri, \& Hanik Wahyu Ningsi \\ Department of Indonesian Language and Literature Education, \\ Faculty of Teacher Training and Education, Universitas Mulawarman \\ Address: Jl. Muara Pahu, Gn. Kelua, Samarinda, East Borneo, 75242 \\ E-mail: widyatmike@fkip.unmul.ac.id
}

Article History: Received 10 February 2020; Accepted 5 August 2021; Published Online 23 August 2021

\begin{abstract}
Language affects society because linguistic forms treat men and women discriminatively as a reflection of the strong influence of language on the culture or habits of the speaking community. This study aimed to describe the representation of gender in speech and language politeness of senior high school and vocational school students in Samarinda City and Kutai Kertanegara Regency. The method used in this research was descriptive qualitative. The results of this study showed first, for the speech form by female students towards female teachers, they dominantly used the following forms: positive speech, expressive speech, and assertive speech. Second, for the speech form of female students towards male teachers, they preferred the form: expressive speech and assertive speech. Third, for the speech form of male students towards female teachers, they used the following forms: positive speech, commissive speech, and assertive speech. Fourth, the speech form of male students towards male teachers was expressive. Fifth, gender representation in student's language politeness showed that female students were more likely to comply and male students were more likely to deviate from the principles of linguistic politeness. This study concludes female students followed the principle of language politeness towards female teachers. Male students expressed more deviations towards male teachers.
\end{abstract}

Keywords: gender representation; language politeness; pragmatic study; speech event

\begin{abstract}
Abstrak
Bahasa memengaruhi masyarakat karena bentuk-bentuk kebahasaaan secara diskriminatif memperlakukan lakilaki dan perempuan sebagai pencerminan kuatnya pengaruh bahasa terhadap budaya atau kebiasaan masyarakat penuturnya. Studi ini bertujuan untuk mendeskripsikan representasi gender dalam tuturan dan kesantunan berbahasa siswa SMA dan SMK di Kota Samarinda dan Kutai Kertanegara. Metode yang digunakan dalam studi ini adalah deskriptif kualitatif. Hasil studi ini menunjukkan pertama, bentuk tuturan siswa perempuan terhadap guru perempuan, siswa perempuan dominan menggunakan bentuk: tuturan impositif, tuturan ekspresif, dan tuturan asertif. Kedua, tuturan siswa perempuan terhadap guru laki-laki, lebih memilih bentuk: tuturan ekspresif dan tuturan asertif. Ketiga, tuturan siswa laki-laki terhadap guru perempuan menggunakan bentuk: tuturan impositif, tuturan komisif, dan asertif. Keempat, tuturan siswa laki-laki terhadap guru laki-laki yaitu tuturan ekspresif. Kelima, representasi gender dalam kesantunan berbahasa siswa menunjukkan bahwa siswa perempuan lebih cenderung melakukan pematuhan dan siswa laki-laki lebih cenderung melakukan penyimpangan pada prinsip kesantunan berbahasa. Studi ini menyimpulkan siswa perempuan mengikuti prinsip kesantunan berbahasa terhadap guru perempuan. Siswa laki-laki lebih banyak mengungkapkan penyimpangan terhadap guru laki-laki.
\end{abstract}

Kata kunci: representasi gender; kesantunan berbahasa; studi pragmatis; peristiwa tutur

\section{Introduction}

The use of language when interacting with speech participants is closely related to two important dimensions in our humanity, including gender (identity) and sexual orientation or more generally our sexuality (Al-Ghamdi et al. 2019). Therefore, as a form of speech associated with gender roles, conversations between teachers and students in classroom learning can be considered to reveal certain politeness values, which in this study are called language politeness. In interacting, rules that regulate 
between the speaker and the interlocutor are needed so that later good communication can be established between the two. These rules can be seen in the language politeness principle proposed by Leech (2014b). Leech divides politeness into six principles, consisting of the tact maxim, the generosity maxim, the approbation maxim, the modesty maxim, the agreement maxim, and the sympathy maxim.

The problem of language politeness and gender as speech construction is still a concern of linguists about three decades ago. All languages have their own manners and politeness systems so that it is not uncommon for people to see that polite habits in language differences between men and women (Freed 1996, Mavisakalyan 2015, Jones 2016, Haavik et al. 2019). Gender is generally defined as sex but is described as the differentiation of roles, functions, and responsibilities between women and men resulting from socio-cultural construction and can change according to the times (Adzawla et al. 2019). Thus, gender has a relationship with social and cultural conditions in a certain place and can be observed in certain fields, one of which is education.

Gender issues in the field of education can be seen from the form of speech between students and teachers in schools during the teaching and learning process. The speech form between students and teachers in schools during the teaching and learning process can be observed to see the overview of gender inequality that occurs in society. There is an unbalanced gender representation in the speech that occurs during the learning process used in the field of education. For example, Papavlasopoulou et al. (2020) concluded from various studies that women are under-represented or negatively represented in terms of (1) visibility, (2) nature, and (3) work, either in text and illustrations.

Rasyid (2018) explained that gender studies related to the language often focus on the differences between the speech used by men and women. A survey conducted by Al-Ghamdi et al. (2019) on various studies on the influence of speaker gender on linguistic variation showed that there are utterances that are exclusively liked by women and other utterances that are exclusively liked by men (Latifa 2021). For example, in interactions between the sexes, women generally ask more questions, use more polite speech, and interrupt less than men. Moreover, contrary to the myth that women talk more than men, the findings of several studies showed that men listen less and talk more than women (Pinto et al. 2019).

The phenomenon of politeness in the learning process needs to be investigated because some of the research results described above cannot be used as a reference to explain politeness patterns involving teachers and students, and in relation to their gender (Steege et al. 2018). Students' politeness towards teachers is increasingly complex in the learning process because of the different speech participants. These differences can be seen in their age, social status, sex, and cultural background, resulting in the use of different forms of language (Buyle \& De Smet 2018). The description that has been stated previously shows that there are problems in the research entitled "Gender Representation and Language Politeness in Speech Acts: A Pragmatic Study".

This study aimed to describe the representation of gender in speech and language politeness of senior high school and vocational school students in the cities of Samarinda and Kutai Kertanegara. Language politeness was outlined in the research question "How is the embodiment of male and female student politeness towards male and female teachers in the interaction of Indonesian language learning in senior high schools or vocational schools in Samarinda City and Kutai Kartanegara Regency? The senior high schools or vocational school students as research subjects were based on the vulnerable age of adolescents when they were in middle school. In addition, the selection of senior high school and vocational school students was due to cultural diversity, ethnicity, geography, and social level or social class between the students and teachers. The researchers assumed that the diversity of culture, ethnicity, geography, and social levels of students and teachers would also show different language characteristics between male and female students. 


\section{Research Method}

This study used a qualitative approach, in which this approach emphasizes narrative development or textual description of the phenomenon under study (Ruggiano \& Perry 2019). In this study, the researchers made a description of the speech event, the degree of politeness, and the gender representation of students in communication. The method used in this research was descriptive qualitative (O'Connor \& Joffe 2020).

The research was conducted in Samarinda City and Kutai Kertanegara Regency, East Kalimantan. In Samarinda, it was implemented in three schools, including State Senior High School (SMAN) I, State Senior High School (SMAN) II, and Erlangga Vocational School (SMK). Meanwhile, in Kutai Kartanegara, it was held at SMKN I, SMKN II, and SMAN I. The selection of high and vocational school students was because of the factors of culture, ethnicity, geography, and social level between the students and teachers. The researchers assumed that the cultural, ethnic, geographical, and social diversity of students and teachers would also show different language characteristics between male and female students (Matthews et al. 2018).

The data collection techniques used observation, recording, and card records. The determination of compliance and deviation from the principle of language courtesy was based on indicators of language courtesy derived from Leech's theory. The data analysis techniques in this study were making a transcription of information from the recordings, identifying, classifying, and clarifying information, copying to information cards, analyzing information cards, and drawing conclusions (Thomann \& Maggetti 2020). The selection of high and vocational school students was because of the factors of culture, ethnicity, geography, and social level between the students and teachers. The researchers assumed that the cultural, ethnic, geographical, and social diversity of students and teachers would also show different language characteristics between male and female students.

\section{Results and Discussion}

\section{Realization of principles of language politeness in male students towards male teachers}

Based on the data obtained in the study, it found compliance and deviance in the principle of language politeness. The overall data collected were based on the number of data cards, which were 56 speech data cards. The data cards in the form of compliance with the principle of language politeness of male students towards male teachers amounted to 6 data or up to $60 \%$, deviations in the principle of language politeness of male students towards male teachers amounted to 4 data or reached $40 \%$, compliance with politeness principles showed that there were 8 male students against female teachers or $61.5 \%$.

There were 5 data deviations from male students towards female teachers or $38.4 \%$ or up to 40 data, the deviation of the principle of language politeness of female students towards male teachers amounted to 6 data or reached $60 \%$, compliance with the principle of language politeness of female students towards female teachers amounted to 12 data or up to $52.1 \%$, and deviation from female students towards female teachers showed that there were 11 data or $47.8 \%$. The realization of principles of language politeness in male students to male teachers is described in Table 1 as follows: 
Table 1.

Realization of principles of language politeness in male students towards male teachers

\section{The approbation maxim Compliance: Data 01.01.01}

Context:

Analysis:
Teacher: I sincerely welcome! Pore! It can be heard!

Student (Lk): Assalamualaikum Warahmatullahi Wabarakatuh. Let me introduce myself. My name is Abdul Arif, a representative of class $X$ MIA 1. Negotiation is the process of bargaining with ways to negotiate to deal with or become a mutual agreement between one party and another. Thank you.

The male student expressed his opinion in polite language.

Data 01.01.01 included compliance with the approbation maxim because the speech of the male student maximized respect for the addressee. The selection of subtle words such as using the word "thank you" makes the opponent feel appreciated. The realization of principles of language politeness in male students towards male teachers.

The approbation maxim and the sympathy maxim

Compliance: Data 01.01.06 Student: (noisy and not paying attention to the teacher)

Teacher: Yes, please! Everyone, listen to your friend!

Student: (The classroom atmosphere was calm again)

Context:

When the teacher invited a student to answer, the classroom atmosphere sounded noisy so the teacher rebuked all students for silence and listened to a friend who would give an answer. The classroom atmosphere was calm again.

Analysis:

Data 01.01.06 included compliance with the approbation maxim and the sympathy maxim because all students were able to appreciate and give sympathy to the teacher. Compliance with the approbation maxim and the sympathy maxim was shown when the students were willing to respect the warning from the teacher to be quiet and listen to their friend who would give an answer. In the speech, the students also showed their sympathy maxim by providing sincere support to the teacher to calm down.

Deviation: Data 01.01.05

Teacher: Be careful when expressing opinions! (A student raised his hand. Meanwhile, the other students were very noisy and did not pay attention to the teacher)

Teacher: Yes, please! Everyone, listen to your friend!

Context: When the teacher invited one student to answer the question, the other students made a fuss. 
Analysis:

The attitude of these students, both male and female students, was included in the deviation of the approbation maxim and the sympathy maxim because all students did not appreciate and give sympathy to the teacher. In these data, all students looked crowded themselves and did not pay attention to the teacher who was speaking.

\begin{tabular}{ll}
\hline The tact maxim & Teacher: Thank you, anyone else? \\
Deviation: Data 01.01.08 & $\begin{array}{l}\text { Student (Lk): He does, sir. He does, sir. } \\
\text { When the teacher asked the other students to answer, a student } \\
\text { yelled asking the teacher so that his friend would answer the } \\
\text { question given by the teacher. } \\
\text { Analysis: }\end{array} \quad \begin{array}{l}\text { The student's speech deviated from the tact maxim because he } \\
\text { asked the teacher so that his friend would answer the question } \\
\text { given by the teacher. The attitude of the student was not polite } \\
\text { because he seemed to instruct the teacher to appoint his friend to } \\
\text { answer the question. }\end{array}$
\end{tabular}

The tact maxim and the generosity maxim

Deviation: Data 01.01.03 Teacher: Mun Agus, can it be mandatory?

Agus: (did not answer)

Context:

Agus was just silent and did not give answers when the teacher asked him.

Analysis:

Agus's attitude that did not answer the teacher's question deviated from the tact maxim and the generosity maxim. Because Agus was not a student, he did not answer Mr. Yamri's question as a teacher. This showed that Agus' attitude that did not answer the question from the teacher means that he was trying to minimize advantage for the teacher and maximize advantage for himself. Even though the student does not know or is not ready to answer, it is recommended that the student responds to questions from the teacher so that the teacher also feels appreciated.

Source: Primary data

\section{Gender representation in student language politeness}

Based on data analysis in the research that has been conducted, it is found compliance and deviation of the principles of language politeness of male and female students in learning the Indonesian language.

Table 2.

Compliance and deviation of the principle of politeness of female students towards female teachers

\begin{tabular}{lcc}
\hline \multicolumn{1}{c}{ Maxim } & Compliance & Deviation \\
\hline Generosity & $3 \%$ & - \\
Approbation & $9 \%$ & - \\
Modesty & $12 \%$ & $3 \%$ \\
Agreement & $9 \%$ & $3 \%$ \\
\hline \multicolumn{3}{c}{}
\end{tabular}

Table 2 explains compliance with the principle of politeness of female students towards the female teacher in the generosity maxim, the approbation maxim, the modesty maxim, and the agreement maxim. However, of the four maxims, the modesty maxim was more dominant with a percentage of $12 \%$. Thus, it can be concluded that the modesty maxim indicated gender representation in complying with the politeness of female students towards female teachers. Meanwhile, the deviation of the principle of language politeness of female students was in the modesty maxim and the agreement maxim. However, the two maxims had the same percentage value so that no maxims dominated. 
Table 3.

Compliance and deviation of the principle of politeness of female students towards male teachers

\begin{tabular}{lcc}
\hline \multicolumn{1}{c}{ Maxim } & Compliance & Deviation \\
\hline Approbation & $3 \%$ & - \\
Modesty & $3 \%$ & $3 \%$ \\
Sympathy & $3 \%$ & - \\
Agreement & - & $3 \%$ \\
\hline
\end{tabular}

Source: Primary data

Table 3 describes compliance and deviation of the principle of language politeness of female students towards male teachers that had the same percentages, no maxim dominated. However, if it is seen based on the number of compliance, female students were more likely to comply with rather than deviate from the principle of language politeness. Thus, it can be concluded that compliance indicated the gender representation of female students.

Table 4.

Compliance and deviation of the principle of politeness of male students towards female teachers

\begin{tabular}{lcc}
\hline \multicolumn{1}{c}{ Maxim } & Compliance & Deviation \\
\hline Tact & $9 \%$ & $3 \%$ \\
Generosity & - & $3 \%$ \\
Approbation & $3 \%$ & - \\
Modesty & $3 \%$ & - \\
Sympathy & $9 \%$ & - \\
\hline
\end{tabular}

Table 4 explains compliance with the principles of language politeness of male students towards the female teacher in the tact maxim, the approbation maxim, the modesty maxim, and the sympathy maxim. However, if it is seen based on the number of percentages, the tact maxim, and the sympathy maxim were the maxims that dominated. Thus, it can be concluded that the tact maxim and the sympathy maxim indicated gender representations in the politeness of male students towards female teachers. Meanwhile, the deviation of the principle of language politeness of male students was in the tact maxim and the generosity maxim. However, the two maxims had the same percentage value so that no maxims dominated.

Table 5.

Compliance and deviation of the principle of politeness of male students towards male teachers

\begin{tabular}{lcc}
\hline \multicolumn{1}{c}{ Maxim } & Compliance & Deviation \\
\hline Modesty & $3 \%$ & - \\
Approbation & - & $3 \%$ \\
Agreement & $3 \%$ & $3 \%$ \\
Sympathy & $3 \%$ & $3 \%$ \\
\hline
\end{tabular}

Source: Primary data

Furthermore, Table 5 describes compliance and deviation of the principles of language politeness of male students towards male teachers that had the same percentage, no maxims dominated. Thus, it can be concluded that the representation of gender in the language politeness of female students and male students towards teachers in the learning process shows compliance and deviations. Female students were more likely to comply with the modesty maxim and male students were more likely to deviate from all maxims. 
Speech events between teachers and students are communication of linguistic interactions. This is because they want to convey information to one another, whether in the form of ideas, intentions, thoughts, feelings, and emotions directly. The speech that occurs during the learning process is a speech event involving two parties, including the speaker and the speech partner. In addition, speech events are also inseparable from context, in which context is everything that causes speech to occur. Based on Dell Hymes' context elements, namely SPEAKING, the speech of high school and vocational school students in Samarinda City is motivated by several differences, from the asymmetrical social status of the speech participants (teachers and students), feeling less "good" or "hesitate", the goals to be achieved, giving appreciation to speech partners, and so on (Leech 2014a).

In this study, it was found the speech form of students and teachers, which this speech form led to the speech form used to express the maxims of language politeness which were then linked to gender, in order to obtain differences in the speech form of female students and male students. The speech form by female students towards female teachers was an impositive speech that functions to create an effect through the actions of the listener. This study found an impossibility statement on female students when learning in the classroom. The female student uttered utterances that cause the teacher to take action as said by her. In addition, this study also found expressive speech among female students, which is speech that functions to express, reveal, or inform the speaker's psychological attitude. This study found expressive speech in female students. These speeches could be found in the words "thank you" and "expressions of forgiveness" from female students which were spoken towards female teachers. The same thing was also found in (Soutar \& Mitchell 2018) who found expressive utterances in the form of "thank you" and "apologies" in their research entitled "Expressive Speech Actions in the Film of Honor Behind the Veil of Director Tya Subiakto Satrio". Expressive speech in the film is a speech intended by the speaker so that the speech can be interpreted as an evaluation of what is mentioned in the speech. Another speech form found in female students' speech towards female teachers was assertive speech. Assertive speech is speech that functions to state the truth of the proposition being expressed (Andreoli \& Olivera 2020).

This study found that assertive speech was used to express the opinions of female students towards female teachers. Meanwhile, there were only 2 speech forms expressed by female students towards male teachers, including expressive speech and assertive speech. Expressive speech of female students towards male teachers was found in the speech of "apologies" and "expressions of shame" of female students towards the teacher's words. The speech is a form of the participants' psychological attitude towards speech partners. Female students seem to be more careful in expressing something, as revealed by (Culpeper \& Gillings 2019) in their book entitled Psychology of Women in Various Perspectives. There are several biases in women's psychology, including the psychology of women who are timid and sensitive. Women are said to be better at expressing emotions. Besides, they are also more sensitive to their own emotions and those of others. In this study, it is clear that female students were more careful in their behavior (Sakip et al. 2015).

Male students' speech towards female teachers did not express orders. This study found a positive statement on a male student when learning in the classroom. The male student uttered a speech which resulted in the teacher taking action as said by the student. In addition, the commissive speech was also found, which is speech that states an offer or promise (Marques et al. 2020). The findings in the study were regarding learning activities in which one of the activities was reading. There were differences of opinion between what the male students and female students wanted regarding the reading activity so that the teacher gave a solution as an offer, then the students agreed to the offer. Another speech form found in this study was the form of assertive speech which is commonly used to state the truth of the proposition expressed. Meanwhile, there was only one variation of speech expressed by male students towards male teachers, which was expressive speech. Therefore, in this study, the speech form of female students was more varied than that of male students. This seems to be in line with the opinion of (Crible et al. 2019) who stated that there were differences between women and men in language. Women's 
language is indecisive, uses figurative words, is careful when expressing things, and uses more refined and polite words, while men's language is more assertive, mature, and men like to speak openly with the right vocabulary.

This research also found obedience and deviation from the modesty principle. The findings of this study indicated that the principle of language politeness of students towards teachers based on gender representations was found to be obedient and irregular in Indonesian language learning interactions. The same thing was also expressed by Febriadina (2018) in her research entitled "Politeness of Male and Female Students in Sragen, Central Java". The researcher conducted research in the socio-pragmatic field in the form of student speech. Vocational school students were involved as research subjects with the research object of student language politeness. The results of the study found differences in the form of language politeness between male students and female students. Musyawir (2017) in his research also found deviations in the principle of politeness in Indonesian language teaching-learning interactions for class XI students of State Senior High School 2 Panca Rijang Sidenreng Rappang. In addition, Dwipayana et al. (2014) conducted a study with the title "Politeness of Speech in the Choice of Language Code for Students in the Community of State Senior High School 1 of Ubud in terms of Gender Perspective: A Socio-pragmatic Study". The results showed positive and negative politeness in the speech of male and female students at State Senior High School 1 of Ubud.

The similarity between these two studies and this research is that they both examined the principles of language politeness in the form of compliance and deviation of the maxims of students towards teachers based on a gender perspective. While the difference between the two studies and this study is that the research subjects combined high school and vocational school in one research subject.

In this study, it was found that compliance and deviation to the principle of politeness were divided into six maxims according to Leech, including: the tact maxim, the generosity maxim, the approbation maxim, the modesty maxim, the agreement maxim, and the sympathy maxim. This compliance and deviation was carried out by both female and male students when learning in class with female or male teachers (Leech 2014b).

Compliance in this study was characterized by the speech of students who responded well when the teacher asked questions. In addition, another form of compliance of the tact maxims is that students raised their hands if they wanted to express their opinions or when students did commissive speech with the teacher. Compliance with the modesty maxim in this study was indicated by students' expressions towards the teacher using the word "thank you" when given the opportunity to express their opinions, when the teacher provided suggestions, and when the teacher closed the learning meeting. Compliance with the modesty maxims was indicated by the speech of students who honestly conveyed their shortcomings. In the modesty maxim, speakers should praise themselves as little as possible and criticize themselves as much as possible. Traugott (2019) stated that if we want to speak politely, as speakers we must be humble towards the other person. Compliance with the agreement maxim was marked by the students' speech that accepted and agreed with the teacher's explanation or answer.

Deviation in this research was indicated by the students' speech which did not maximize the advantage for the speech partner, in this case, the teacher. Students as speech participants should be able to use strategies in interacting, which are speaking clearly, being polite, and always paying attention to the values of supporting language politeness (Mugford 2020). Another form of deviation was found in the tact maxim which was marked by the student's speech "no, ma' am, no" when asked about repeating the explanation of the teaching material. This was a deviant attitude because the student did not accept the offer given by the teacher (Dwiyono et al. 2021). Another deviation was the generosity maxim, in which students as speech participants maximizing advantage for themselves by saying "Sapri, Ma'am!" This was a deviation from the generosity maxim because the student shouted asking the teacher to appoint another student to answer questions. Deviation to the modesty maxim was indicated by the response of students' answers that were not polite "Aaahhh ..." when the teacher will repeat the explanation 
of the teaching material and another deviation was that students did not thank the teacher as speech partners when given suggestions, instead, the student simply answers "oh... I see". Deviations from the agreement maxim were indicated by the saying "I do not agree" in the speech. It can be seen that speakers cannot make agreements with their classmates.

\section{Conclusion}

Based on the findings and discussion of research on the principle of language politeness in students towards teachers in the interaction of learning the Indonesian language in senior high school and vocational school in Samarinda City and Kutai Kartanegara Regency, it can be concluded that the principle of language politeness of female students towards female teachers and male teachers in Indonesian language learning interactions equally showed the compliance and deviation of the principle of language politeness. Female students more often adhered to the principle of language politeness towards female teachers than towards male teachers and more often did deviations towards male teachers than towards female teachers. The compliance with the principle of language politeness done by female students towards female teachers was more than the deviation. Meanwhile, the principle of language politeness of male students towards female teachers and male teachers in Indonesian language learning interactions both showed the obedience and deviations of the principle of language politeness. Male students more often complied with the principle of language politeness towards female teachers compared towards male teachers and more often did deviations towards male teachers than towards female teachers. However, the compliance with the principle of language politeness practiced by male students towards male teachers was more than the deviation.

Gender representation in students' language politeness showed that female students were more likely to comply with and male students were more likely to deviate from the principle of language politeness. Compliance to the principle of politeness for female students was found in (1) the generosity maxims, (2) the approbation maxim, (3) the modesty maxim, (4) the agreement maxim, while deviations were in (1) the modesty maxim and (2) the agreement maxim. Compliance with the principle of language politeness of male students was found in (1) the tact maxim, (2) the approbation maxim, (3) the modesty maxim, (4) the sympathy maxim. Meanwhile, deviations were found in (1) the tact maxim, (2) the generosity maxim, (3) the approbation maxim, (4) the agreement maxim, and (5) the sympathy maxim. Thus, the principle of language politeness based on gender in the interaction of Indonesian language learning in senior high school and vocational school in Samarinda City and Kutai Kartanegara Regency showed compliance and deviation. Female students followed the principle of language politeness towards female teachers. Male students expressed more deviations towards male teachers.

\section{References}

Adzawla W, Azumah SB, Anani PY, \& Donkoh SA (2019) Gender perspectives of climate change adaptation in two selected districts of Ghana. Heliyon 5 (11):e02854. https://doi.org/https://doi. org/10.1016/j.heliyon.2019.e02854.

Al-Ghamdi NA, Almansoob NT, \& Alrefaee Y (2019) Pragmatic failure in the realization of the speech act of responding to compliments among yemeni EFL undergraduates. 3L: Language, Linguistics, Literature 25 (4):227-240. https://doi.org/10.17576/3L-2019-2504-14.

Andreoli F \& Olivera J (2020) Preferences for redistribution and exposure to tax-benefit schemes in Europe. European Journal of Political Economy 63 (March):101880. https://doi.org/10.1016/j. ejpoleco.2020.101880.

Buyle A \& De Smet H (2018) Meaning in a changing paradigm: The semantics of you and the pragmatics of thou. Language Sciences 68: 42-55. https://doi.org/10.1016/j.langsci.2017.12.004.

Crible L, Abuczki Á, Burkšaitienė N, Furkó P, Nedoluzhko A, Rackevičienė S, \& Zikánová Š (2019) Functions and translations of discourse markers in TED talks: A parallel corpus study of underspecification in five languages. Journal of Pragmatics 142: 139-155. 
Culpeper J \& Gillings M (2019) Pragmatics: Data trends. Journal of Pragmatics 145: 4-14. https://doi. org/10.1016/j.pragma.2019.01.004.

Dwipayana IKA, Sudiana IN, \& Sutama IM (2014) Kesantunan tuturan dalam pilihan kode bahasa siswa di komunitas SMAN 1 Ubud ditinjau dari perspektif gender: Sebuah kajian sosiopragmatik. Jurnal Pendidikan Dan Pembelajaran Bahasa Indonesia 3 (1):1-10.

Dwiyono Y, Mulawarman WG, Panji OP, Salaim NA, Ikhsan M (2021) Implementation of national examination based on computer based test at Vocational School 1 North Sangatta. Cypriot Journal of Educational 16 (1):86-95. https://doi.org/10.18844/cjes.v16i1.5510.

Febriadina ZF (2018) Kesantunan berbahasa dalam interaksi pembelajaran bahasa Indonesia di kelas XI SMK Negeri 1 Plupuh Sragen. Thesis, Universitas Sebelas Maret, Surakarta.

Freed AF (1996) Language and Gender Research in An Experimental Setting 1. London: Routledge.

Haavik TK, Antonsen S, Rosness R, \& Hale A (2019) HRO and RE: A pragmatic perspective. Safety Science 117: 479-489. https://doi.org/10.1016/j.ssci.2016.08.010.

Jones L (2016) Language and Gender Identities. London: Routledge.

Latifa A (2021) Language varieties of woman's conversation in yutube channel of Emma Watson in HeForShe program: A conversation analysis study. International Journal of Linguistics, Literature and Translation 4 (1):221-227. https://doi.org/10.32996/ijllt.2021.4.1.22.

Leech GN (2014a) A Linguistic Guide to English Poetry (Vol. 4). London: Routledge.

Leech GN (2014b) The Pragmatics of Politeness. USA: Oxford University Press.

Marques I, Remington T, \& Bazavliuk V (2020) Encouraging skill development: Evidence from publicprivate partnerships in education in Russia's regions. European Journal of Political Economy 63 (May 2019):101888. https://doi.org/10.1016/j.ejpoleco.2020.101888.

Matthews D, Biney H, \& Abbot-Smith K (2018) Individual differences in children's pragmatic ability: A review of associations with formal language, social cognition, and executive functions. Language Learning and Development 14 (3):186-223. https://doi.org/10.1080/15475441.2018.1455584.

Mavisakalyan A (2015) Gender in language and gender in employment. Oxford Development Studies 43 (4):403-424. https://doi.org/10.1080/13600818.2015.1045857.

Mugford G (2020) Mexican politeness: An empirical study on the reasons underlying/motivating practices to construct local interpersonal relationships. Russian Journal of Linguistics 24 (1):3155. https://doi.org/10.22363/2687-0088-2020-24-1-31-55.

Musyawir M (2017) Penyimpangan prinsip kesantunan berbahasa dalam interaksi belajar-mengajar Bahasa Indonesia siswa kelas XI SMA Negeri 2 Panca Rijang Sidenreng Rappang. Thesis, Universitas Negeri Makassar, Makassar.

O'Connor C \& Joffe H (2020) Intercoder reliability in qualitative research: Debates and practical Guidelines. International Journal of Qualitative Methods 19: 1-13. https://doi. org/10.1177/1609406919899220.

Papavlasopoulou S, Sharma K, \& Giannakos MN (2020) Coding activities for children: Coupling eyetracking with qualitative data to investigate gender differences. Computers in Human Behavior 105: 105939. https://doi.org/10.1016/j.chb.2019.03.003.

Pinto M, Sales D, \& Fernández-Pascual R (2019) Gender perspective on information literacy: An interdisciplinary and multidimensional analysis within higher education settings. Library and Information Science Research 41 (4):100979. https://doi.org/10.1016/j.lisr.2019.100979.

Rasyid R (2018) Analisis kesantunan berbahasa berbasis gender dalam interaksi pembelajaran Bahasa Indonesia di SMA Negeri 6 Sidenreng Rappang. Thesis, Universitas Negeri Makassar, Makassar.

Ruggiano N \& Perry TE (2019) Conducting secondary analysis of qualitative data: Should we, can we, and how? Qualitative Social Work 18 (1):81-97. https://doi.org/10.1177/1473325017700701.

Sakip SRM, Akhir NM, \& Omar SS (2015) Determinant factors of successful public parks in Malaysia. Procedia - Social and Behavioral Sciences 170: 422-432. https://oi.org/10.1016/j. sbspro.2015.01.003.

Soutar I \& Mitchell C (2018) Towards pragmatic narratives of societal engagement in the UK energy system. Energy Research and Social Science 35 (October 2017):132-139. https://doi.org/10.1016/j. erss.2017.10.041. 
Steege R, Taegtmeyer M, McCollum R, Hawkins K, Ormel H, Kok M, \& Theobald S (2018) How do gender relations affect the working lives of close to community health service providers? Empirical research, a review and conceptual framework. Social Science and Medicine 209 (November 2017):1-13. https://doi.org/10.1016/j.socscimed.2018.05.002.

Thomann E \& Maggetti M (2020) Designing research with qualitative comparative analysis (QCA): Approaches, challenges, and tools. Sociological Methods and Research 49 (2):356-386. https:// doi.org/10.1177/0049124117729700.

Traugott EC (2019) Whither historical pragmatics? A cognitively-oriented perspective. Journal of Pragmatics 145: 25-30. https://doi.org/10.1016/j.pragma.2019.01.006. 